\title{
A Case of Intracranial Hypotension Complicated with Hydrocephalus
}

\section{Hidrosefali ile Komplike Olan Bir Intraventriküler Hipotansiyon Vakası}

\begin{abstract}
AIM: Intracranial hypotension may have variable clinical presentation. The imaging characteristics of intracranial hypotension are especially well depicted on magnetic resonance imaging studies. Although the clinical and radiological manifestations of spontaneous intracranial hypotension are increasingly recognized in many reports, many other abnormalities in this disorder and complicating cases still exist.
\end{abstract}

MATERIAL and METHODS: A 16-year-old patient suffering from nausea, vomiting and blurred consciousness was admitted to the hospital. MRI showed diffuse pachymeningeal thickening resembling intracranial hypotension and ventricular enlargement like compensated hydrocephalus. The patient was investigated and treated using endoscopic third ventriculostomy.

CONCLUSION: The authors presented a case of intracranial hypotension complicated with hydrocephalus. Specific causes for intracranial hypotension as well as additional new treatment options will also be discussed.

KEYWORDS: Intracranial hypotension, Triventricular hydrocephalus, Lumbar puncture, Herniation

\section{ÖZ}

AMAÇ: İntrakranial hipotansiyon farklı klinik bulgular verebilen bir antitedir. MRI bulguları literatürde ayrıntılı olarak tarif edilmekle birlikte, nöroşirürji pratiğinde her zaman akla gelmemektedir. Aynı bulguların farklı sinir sistemi hastalıklarında da görülebilmesi, vakaları komplike hale getirmektedir.

YÖNTEM ve GEREÇ: 16 yaşında bayan hasta bulantı-kusma ve bilinç bulanıklığı nedeniyle hastanemize yatırıldı. MRI intrakranial hipotansiyonla uyumlu difüz pakimeningeal kalınlaşma ve kontrast tutulumu ve eşlik eden triventriküler genişleme gösterdi. Hasta ayrıntılı olarak incelendi ve endoskopik yolla 3 . ventrikülostomi yapılarak tedavi edildi.

SONUÇ: Yazarlar, arrest hidrosefali ile komplike olan bir intrakranial hipotansiyon vakasını sunmuş ve tedavi yöntemi ile birlikte tartışmışlardır. Endoskopik 3. ventrikülostomi, bu vaka için tanı koydurucu ve emniyetli bir seçenek olmuştur. ANAHTAR SÖZCÜKLER: İntrakranial hipotansiyon, Triventriküler hidrosefali, Lomber ponksiyon, Herniasyon

\section{Pinar OZISIK \\ Mustafa BERKER \\ Bulent ONAL}

Hacettepe University, Faculty of Medicine, Department of Neurosurgery, Ankara, Turkey

Received : 08.08.2009

Accepted : 24.08.2009

Correspondence address:

Pinar OZISIK

Phone : +90 3125932929

E-mail : kozisik@hotmail.com 


\section{INTRODUCTION}

Intracranial hypotension (ICH) is no longer a rare syndrome of diverse origin. During the last decade, more than 200 studies have described spontaneous $\mathrm{ICH}$. It is characterized by a postural headache associated with a low cerebrospinal fluid (CSF) pressure with no history of previous dural trauma or invasive treatment of the spine (22), although patients with chronic headaches or even no headache have been described (24). The diagnosis of ICH can usually be confirmed by demonstrating decreased CSF opening pressure on a lumbar puncture (LP), often less than $60 \mathrm{~mm} \mathrm{H}_{2} \mathrm{O}$. In some cases, spinal pressure may be so low that Valsalva's test or gentle aspiration with a syringe is required to obtain CSF (4).

Advances in neuroimaging have improved to diagnose $\mathrm{ICH}$ as well as its varied modes of presentation. Especially, findings on magnetic resonanceimaging(MRI) studies that are characteristic of this syndrome have allowed physicians to realize its true incidence. Since Schaltenbrand (27) first reported pachymeningeal enhancement in $\mathrm{ICH}$ as a cause of postural headache, the clinical and radiological manifestations of $\mathrm{ICH}$ are increasingly recognized in many reports. However, many other abnormalities $(3,5,19,21)$ in this disorder and complicating cases still exist.

Three mechanisms are proposed to explain low CFS pressure: 1) diminished CSF production; 2) hyperabsorption of CSF; and 3) CSF leakage through small meningeal lacerations (27). Several authors reported cases in which spontaneous spinal CSF leakage through congenital meningeal fistulas resulted in the characteristic postural headache of spontaneous ICH $(13,19)$. Nonetheless, symptoms of ICH may be caused any time the duramater is traumatized, such as after diagnostic LP, myelography, spinal anesthesia, spinal injury, and spinal surgery $(6,20,33)$, craniotomy or placement of a ventriculoperitoneal shunt (18). Systemic diseases such as dehydration, diabetic coma, uremia and, hyperpnea are the other medical causes of ICH (8).

In this paper, we present a case of ICH complicated with enlarged ventricles representing a compensated hydrocephalus, and specific causes as well as new treatment options will also be considered.

\section{Patient}

A 16-year-old female no previous history of trauma, meningitis, or central nervous system surgery was admitted with severe headache, neck stiffness, nausea, vomiting, and clouding of consciousness to another hospital. The family gave a history of intermittent headache, but it had got severe in the last 7-10 days before admittance to hospital. Diagnostic LP was performed to exclude meningitis. The chemical and microscopical analysis of CSF was normal. Her emergent cranial computerized tomography (CT) showed moderately enlarged ventricles without any intracranial hemorrhage or mass (Figure 1A, B). She was referred to our hospital 4 days later for hydrocephalus. On admission she was sleepy, with blurred consciousness, neck stiffness, right sixth nerve palsy, upward gaze palsy, nausea, and vomiting. She was waking up rarely with crying and complaining of a severe headache. MRI showed diffuse pachymeningeal thickening and enhancement with subtle enlargement of the pituitary gland. Thick enhancement was seen in the dura of the frontal, parietal, retroclival regions, and in the falx and tentorium (Figure 2A,B). The thickness of increased dural enhancement was also observed in the parasagittal parietal areas. The ventricles were still enlarged but there was no subdural fluid

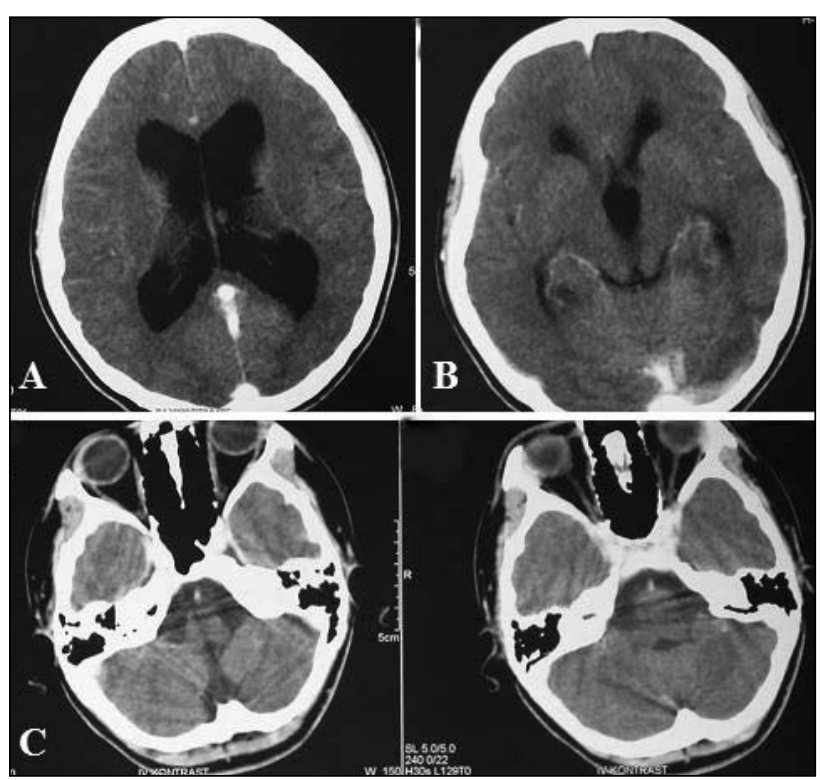

Figure 1: (A) Axial contrast enhanced cranial computerized tomography images showing moderate enlargement of the lateral ventricles; and $(B)$ third ventricle associated with $(C)$ normal-sized fourth ventricle, resembling a triventricular hydrocephalus. 

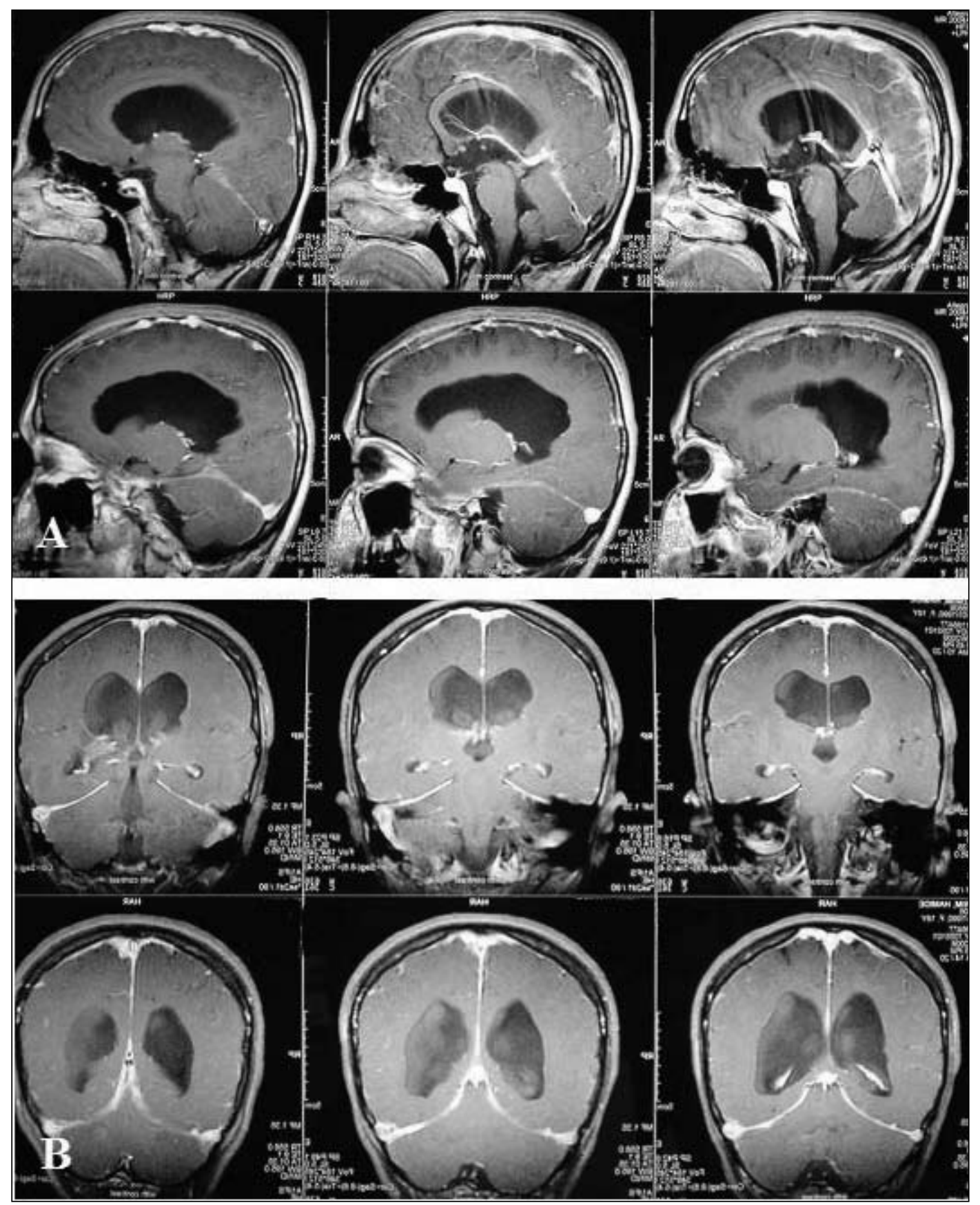

Figure 2: Magnetic resonance images obtained in the patient before treatment. (A) sagittal post-Gd T1-weighted image of the brain demonstrating intense dural enhancement along the clivus and enlargement of the pituitary gland. (B) coronal T1-weighted, Gdenhanced MRI scan of patient showing intense pachymeningeal enhancement over the convexity and along the tentorium.

collection or downward displacement of the brain. Detailed examination of the enhancement pattern suggested that it could be the result of intracranial hypotension due to the diagnostic LP but we could not be sure that the beginning of her symptoms before LP was due to spontaneous CSF leaks through a congenital dural defect or decompensation of arrested hydrocephalus. Whole spine MRI and MR myelography were therefore performed and showed no CSF leakage along the spinal cord (Figure 3)

Corticosteroids and analgesics were administered for her symptoms, but they did not regress. Therefore, a treatment plan was made to relieve her symptoms by taking into account the existence of hydrocephalus. Consequently, endoscopic third 


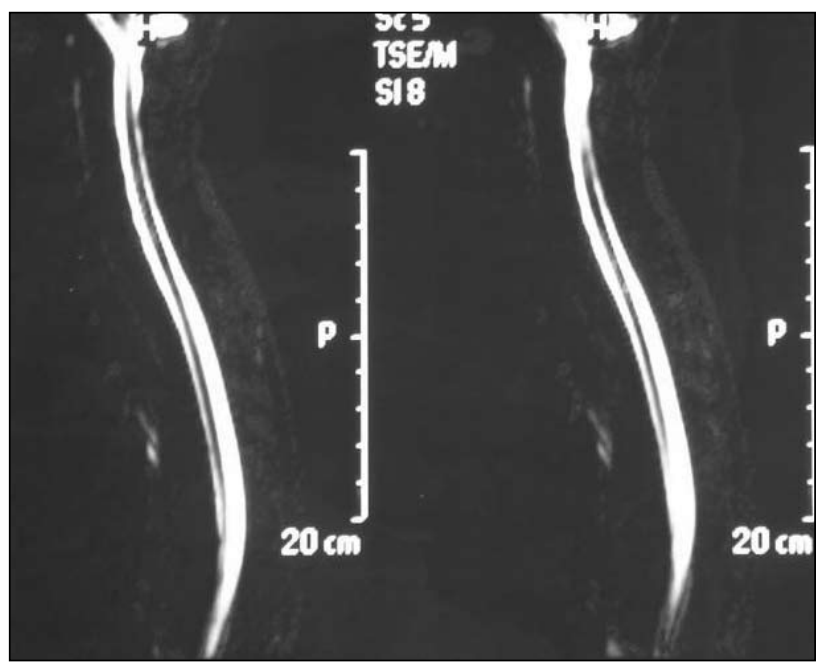

Figure 3: Magnetic resonance myelography showing no dural fistulas for CSF leak along the spinal axis.

ventriculostomy (ETV) was performed. During the entrance of the anterior horn of the right lateral ventricle, the opening pressure was low $(30 \mathrm{mmCSF})$. A new CSF sample was taken to exclude infection and we were able to take dural biopsy with arachnoid from the right frontal area too. Then the opening of floor of third ventricle to the interpedincular cistern was made without any technical complication. An external ventricular drainage was inserted after finishing ETV, but kept closed. The patient's status improved immediately after the operation. She was totally awake and conscious. Next day she had no right sixth nerve palsy, upward gaze palsy, or neck stiffness. The external ventricular drainage was removed on postoperative day $1^{\text {st }}$. Cytological and microbiological characteristic of the CSF and the histopathological examination of the dura were reported as normal. Four months later she came with a new MRI showing that the enhancement of the dura had disappeared (Figure 4A,B) and the ETV was working (Figure $4 \mathrm{C}$ ). She recovered very well and is neurologically normal.

\section{DISCUSSION}

Orthostaticheadache is the principal manifestation of spontaneous $\mathrm{ICH}$, associated with low CSF pressure, whereas CSF pressure and the clinical manifestations are variables depending on the loss of CSF volume (24). A consequence of CSF volume depletion is the descent of thebrain that causes traction or distortion of various central and peripheral painsensitive structures of neuraxis, causing orthostatic or primary headaches and the other clinical findings
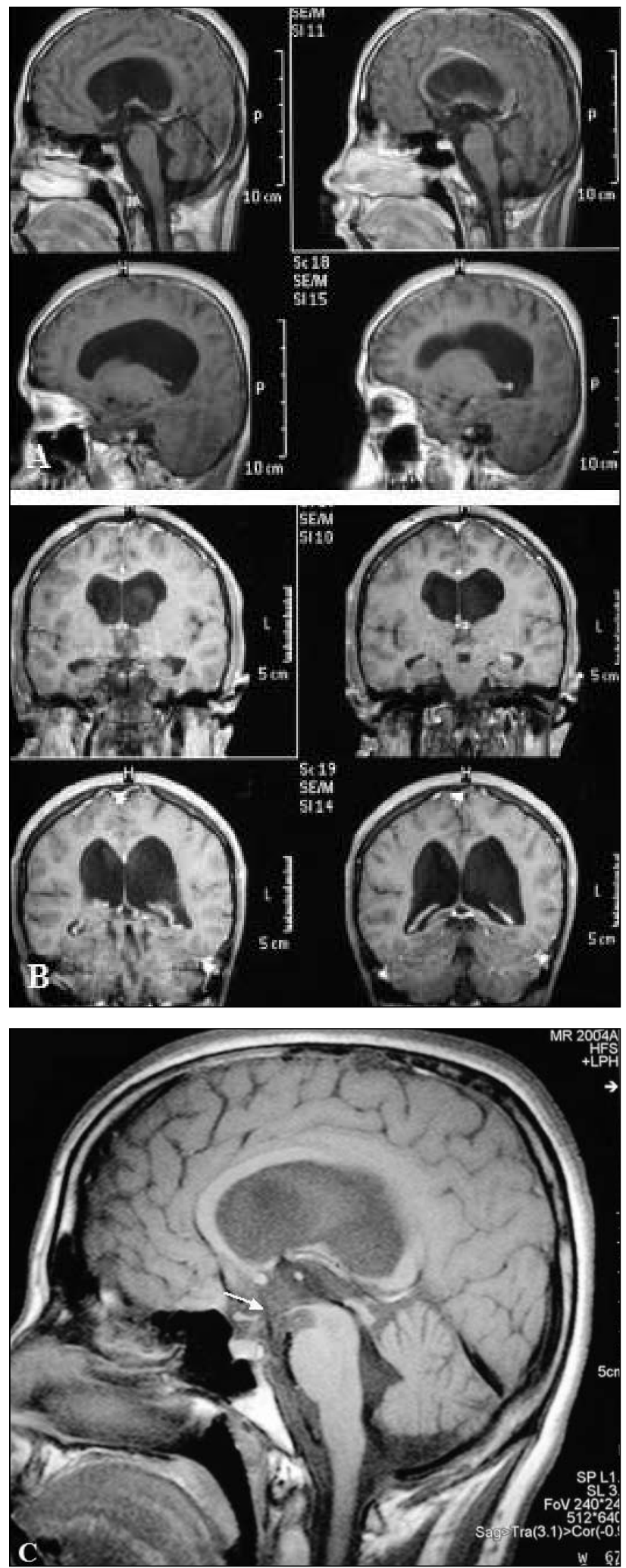

Figure 4: Magnetic resonance imaging 4 months after treatment. (A) sagittal and (B) coronal post-Gd T1-weighted image of the brain demonstrating resolution of typical signs demonstrated in Figure-2. (C) sagittal flair MR image shows the CSF flow artifact (white arrow) through the ETV opening at the floor of third ventricle. 
such as diplopia, photophobia, nausea, hyperacusis, vomiting, bradycardia, nystagmus, abducens nerve palsy, binasal visual field restriction, neck stiffness, dizziness, tinnitus, vertigo, and disturbances of equilibrium. Mental symptoms may occur as well, including clouding of consciousness, mental impairment and drowsiness $(30,33)$. ICH, whatever its cause, is associated with subdural hematoma in $10 \%$ of cases $(20,31,34)$. Spinal CSF leaks in spontaneous $\mathrm{ICH}$ patients are mostly located at the cervical and upper thoracic region. Multiple simultaneous spinal CSF leaks in patients at presentation have also been well described $(13,28,29)$.

All the symptoms of $\mathrm{ICH}$ mentioned above can be complicated easily with the symptomatology of hydrocephalus such as increase of intracranial pressure. The awareness of the typical magnetic resonance images of $\mathrm{ICH}$ make the diagnosis. The pathogenic mechanism of extradural enhancement may be attributable to the vascular dilatation of dural arteries and medullary and cortical veins to compensate for reduced CSF volume and a greater volume of gadolinium remaining in the dilated extradural microvasculature and diffusing into the extradural interstitial fluid $(7,20)$. Non-hypotensive pachymeningealenhancementmay resultfromvarious dural tissue responses to infection, immunological mechanisms, systemic or regional granulomatosis, cancer metastasis, various connective tissue diseases, or other unknown causes $(3,12,14,17,32)$. That is why the biochemical and microbiological examinations of CSF and the histopathological evaluation of dura and arachnoid mater were needed to assure the diagnosis of ICH.

The CSF pressure of our patient was obtained objectively via ventricular puncture at the beginning of ETV procedure, but we did not use intracranial pressure monitoring in order to document postural hypotension. The issue that complicated planning the treatment was her triventricular hydrocephalus. The beginning of her symptoms before LP might have been due to decompensation of arrested hydrocephalus and the LP could worsen the patient's clinical picture and in time it could cause $\mathrm{ICH}$. On the other hand, she could have spontaneous CSF leaks through a congenital dural defect along the spinal axis and all symptoms could be due to CSF hypovolemia and sagging of the brain. To confirm the diagnosis, radiological studies, such as brain and spine MRI with gadolinium enhancement,
CT myelography, radionuclide cisternography are required. Spinal MRI seems to be more sensitive than conventional radionuclide cisternography for detecting CSF leaks $(1,2,9,10,19)$. Therefore, whole spine MRI with gadolinium and MR myelography were performed showing no spontaneous CSF leak. However, CSF leak is so rapid that the accurate site of leakage cannot be found in some patients (15) and the patient had already undergone an LP and leak was expected through that site.

Many reports describe $\mathrm{ICH}$ as having a benign course after conservative management and bed rest $(19,23,24)$. Some medications such as intravenous or oral caffeine, theophylline and methylxanthines are effective for headache in cases of ICH caused by LP (18). Conservative treatments used to restore CSF volume include intravenous or oral hydration, increased salt intake, carbon dioxide inhalation, and steroid therapy. Although steroid treatment has been coincident with some patients' clinical improvement, other studies had contradictory results $(18,21)$. When these measures fail, epidural blood patches are generally considered to be a safe and effective treatment $(16,25)$. Epidural injection of fibrin glue has also shown encouraging preliminary results. Complete resolution of headache is achieved less often in patients with multiple CSF leaks (11). However, few studies have reported the long-term results and recurrence rate of patients indicating the importance of periodic follow-up examinations and developing more effective treatment modalities $(15,26,29)$.

In our patient with severe and progressive neurological impairment, we had to decide quickly on an effective and safe treatment modality. To the best of our knowledge this is the first case in which an ETV was used for the treatment of ICH. It was very useful and safe to measure the ventricular pressure objectively, to have a biopsy of dura and arachnoid mater, and to treat the patient's triventricular hydrocephalus without placement of any hardware and to make the triventricular hydrocephalus communicate with the spinal subarachnoid space. We did not consider an epidural blood patch as we did not show the spinal CSF leak.

In particular, ETV gave us the opportunity to manipulate such a complication after treatment of $\mathrm{ICH}$ in this patient. We could measure intracranial pressure through LP, and drain CSF to treat the 
intracranial hypertension. The history of the disorder and the time interval between the headache onset and clinical symptoms were not clear in this patient and she had not undergone any other neuroradiological examination before. It was therefore not possible to indicate whether the ICH was the underlying cause or merely an epiphenomenon like "spontaneous intracranial hypotension ( $\mathrm{SICH})$ " in this case. That is why we thought that another LP could aggravate the symptoms of the patient. It is still unclear how ETV resolved the symptoms of ICH. Although we did not show the CSF leak along the spine, some blood introduced into the CSF due to the ETV procedure might cause relief by sealing the meningeal tears with resultant chemical meningitis. The use of MRI is necessary in a patient presenting with headache associated with neurological symptoms. The correlation of headache, if possible, with the patient position, a recent history of LP, or an accompanying cranial nerve deficit should trigger a suspicion of $\mathrm{ICH}$. Complicating images can be found in radiological studies such as enlarged ventricles representing a totally opposite diagnosis such as intracranial hypertension. The lack of the prospective studies that are necessary to compare the time course and severity of gadolinium changes with the degree of persistent headache also causes difficulty in planning the treatment. In conclusion, ETV should be taken into account as the accurate, safe and, simple procedure for the diagnosis and treatment of patients with enlarged ventricles accompanied with complicating issues like intracranial hypotension.

\section{ABBREVIATIONS}

CSF: Cerebrospinal fluid

CT: Computerized tomography

ETV: Endoscopic third ventriculostomy

ICH: Intracranial hypotension

LP: Lumbar puncture

MRI: Magnetic resonance imaging

\section{REFERENCES}

1. Albayram S, Wasserman BA, Yousem DM, Wityk R: Intracranial hypotension as a cause of radiculopathy from cervical epidural venous engorgement: Case report. AJNR 23:618-621, 2002

2. Bai J, Yokoyama K, Kinuya S, Konishi S, Michigishi T, Tonami $\mathrm{N}$ : Radionuclide cisternogrphy in intracranial hypotension syndrome. Ann Nucl Med 16:75-78, 2002

3. Bang OY, Kim DI, Yoon SR, Choi IS: Idiopathic hypertrophic pachymeningeal lesions: Correlation between clinical patterns and neuroimaging characteristics. Eur Neurol 39:49-56, 1998
4. Bell WE, Joynt RJ, Sahs AL: Low spinal fluid pressure syndromes. Neurology 10:512-521, 1960

5. Blank SC, Shakir RA, Bindoff LA, Bradey N: Spontaneous intracranial hypotension: Clinical and magnetic resonance imaging characteristics. Clin Neurol Neurosurg 99:199-204, 1997

6. Bourekas EC, Lewin JS, Lanzieri CF: Postcontrast meningeal MR enhancement secondary to intracranial hypotension caused by lumbar puncture. J Comput Assist Tomogr 19: 299-301, 1995

7. Brightbill TC, Goodwin RS, Ford RG: Magnetic resonance imaging of intracranial hypotension syndrome with pathophysiological correlation. Headache 40:292-299, 2000

8. Bruera O, Bonamico L, Giglio JA, Sinay V, Leston JA, Figuerola ML: Intracranial hypotension: The nonspecific nature of MRI findings. Headache 40: 848-852, 2000

9. Chen CJ, Lee TH, Hsu HL, Tseng YC, Wong YC, Wang LJ: Spinal MR findings in spontaneous intracranial hypotension. Neuroradiology 44:996-1003, 2002

10. Chiapparini L, Farina L, D'Incerti L, Erbetta A, Pareyson D, Carriero MR, Savoiardo M: Spinal radiological findings in nine patients with spontaneous intracranial hypotension. Neuroradiology 44:143-152, 2002

11. Chung SJ, Kim JS, Lee MC: Syndrome of cerebral spinal fluid hypovolemia: Clinical and imaging features and outcomes. Neurology 55:1321-1327, 2000

12. Fukui MB, Meltzer CC, Kanal E, Smirniotopoulos JG: MR imaging of the meninges. Part II. Neoplastic disease. Radiology 201:605-612, 1996

13. Jeon TJ, Lee JD, Lee BI, Kim DI, Yoo HS: Radionuclide cisternogrphy in spontaneous intracranial hypotension with simultaneous leaks at the cervicothoracic and lumbar levels. Clin Nucl Med 26:114-116, 2001

14. Kawano Y, Kira J: Chronic hypertrophic cranial pachymeningitis associated with HTLV-1 infection. J Neurol Neurosurg Psychiatry 59:435-437, 1995

15. Kong DS, Park K, Nam DH, Lee JI, Kim JS, Eoh W, Kim $\mathrm{JH}$ : Clinical features and long-term results of spontaneous intracranial hypotension. Neurosurg 57:91-96, 2005

16. Leibold RA, Yealy DM, Coppola M, Cantees KK: Post-dural puncture headache: Characteristics, management, and prevention. Ann Emerg Med 22:1863-1870, 1993

17. Li JY, Lai PH, Lam HC, Lu LY, Cheng HH, Lee JK, Lo YK: Hypertrophic cranial pachymeningitis and lymphocytic hypophysitis in Sjogren's syndrome. Neurology 52:420-423, 1999

18. Marcelis J, Silberstein SD: Spontaneous low cerebrospinal fluid pressure headache. Headache 30:192-196, 1990

19. Miyazawa K, Shiga $Y$, Hasegawa T, Endoh M, Okita N, Higano S, Takahashi S, Itoyama Y: CSF hypovolemia versus intracranial hypotension in "spontaneous intracranial hypotension syndrome". Neurology 60:941-947, 2003

20. Moayeri NN, Hensun JW, Schaefer PW, Zervas NT: Spinal dural enhancement on magnetic resonance imaging associated with spontaneous intracranial hypotension. Report of three cases and review of the literature. J Neurosurg 88: 912-918, 1998

21. Mokri B, Piepgras DG, Miller GM: Syndrome of orthostatic headaches and diffuse pachymeningeal gadolinium enhancement. Mayo Clin Proc 72:400-413, 1997 
22. Mokri B: Headaches caused by decreased intracranial pressure: Diagnosis and management. Curr Opin Neurol 16:319-326, 2003

23. Mokri B: Intracranial hypertension after treatment of spontaneous cerebrospinal fluid leaks. Mayo Clin Proc 77: 1241-1246, 2002

24. Mokri B: Spontaneous cerebrospinal fluid leaks: From intracranial hypotension to cerebrospinal fluid hypovolemiaevolution of a concept. Mayo Clin Proc 74: 1113-1123, 1999

25. Raskin NH: Lumbar puncture headache: A review. Headache 30: 197-200, 1990

26. Sato Y, Honda Y, Maruoka H, Fujimatsu Y, Oizumi K: Recurrence of spontaneous intracranial hypotension with subdural hematomas. Cephalalgia 17: 42-45, 1997

27. Schaltenbrand G: Neuere Anschauungen zur Pathophysiologie der Liquorzirkulation. Zentralbl Neurochir 3:290-299, 1938

28. Schievink VI, Jacques L: Recurrent spontaneous spinal cerebrospinal fluid leak associated with "nude nerve root" syndrome: Case report. Neurosurgery 53:1216-1219, 2003
29. Schievink VI, Maya MM, Riedinger M: Recurrent spontaneous spinal cerebrospinal fluid leaks and intracranial hypotension: A prospective study. J Neurosurg 99:840-842, 2003

30. Sharma A: Preventing headache after lumbar puncture. BMJ 317:1588-1589, 1998

31. Sipe JC, Zyroff J, Waltz TA: Primary intracranial hypotension and bilateral isodense subdural hematomas. Neurology 31: 334-337, 1981

32. Tosaka M, Tamura M, Oriuchi N, Horikoshi M, Joshita T, Sugawara K, Kobayashi S, Kohga H, Yoshida T, Sasaki T: Cerebrospinal fluid immunocytochemical analysis and neuroimaging in the diagnosis of primary leptomeningeal melanoma. Case report. J Neurosurg 94:528-532, 2001

33. Wange LP, Schmidt JF: Central nervous side effects after lumbar puncture. Dan Med Bull 44:79-81, 1997

34. Wyble SW, Bayhi D, Webre D, Viswanathan S: Bilateral subdural hematomas after dural puncture: Delayed diagnosis after false negative computed tomography scan without contrast. Reg Anesth 17:52-53, 1992 